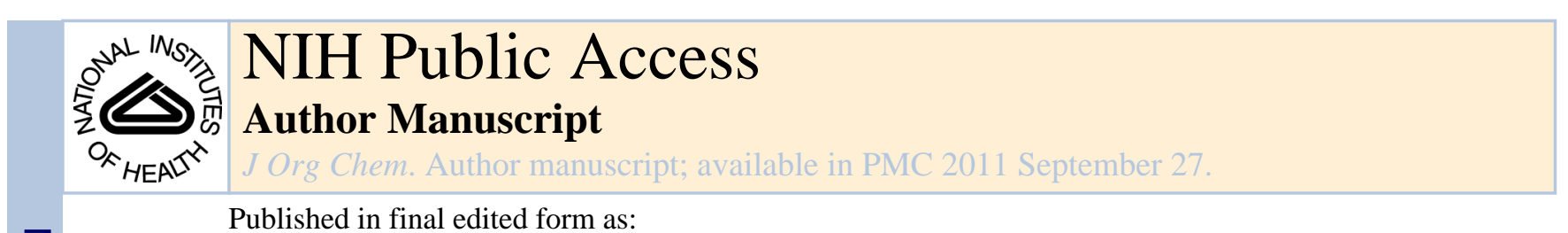

J Org Chem. 2008 January 4; 73(1): 157-161. doi:10.1021/jo7018812.

\title{
A Total Synthesis of OSW-1
}

Jie Xue, Peng Liu, Yanbin Pan, and Zhongwu Guo*

Department of Chemistry, Wayne State University, 5101 Cass Avenue, Detroit, Ml 48202

\begin{abstract}
A new and practical method was developed to synthesize OSW-1, a natural saponin with potent antitumor activities, from (+)-dehydroisoandrosterone, ${ }_{\mathrm{L}}$-arabinose and $\mathrm{D}$-xylose on gram scale. The synthesis was achieved in 10 linear steps with an overall yield of $6.4 \%$ starting from (+)dehydroisoandrosterone.
\end{abstract}

\section{Keywords}

carbohydrate; saponin; OSW-1; total synthesis

\section{Introduction}

OSW-1 (1) is a steroidal saponin isolated from Ornithogalum saundersid, ${ }^{1}$ which belongs to a group of cholestane glycosides. The structure of OSW-1 is rather unique in that its disaccharide moiety linked to the steroidal aglycone $O-16$ position contains a $p$ methoxybenzoyl group. OSW-1 has exhibited exceptionally potent cytotoxicity, ${ }^{2,3}$ with $\mathrm{IC}_{50}$ between 0.1 and $0.7 \mathrm{nM}$, to a variety of malignant tumor cells, including leukemia, mastrocarcinoma, lung adenocarcinoma, pulmonary large cell carcinoma, and pulmonary squamous cell carcinoma. Therefore, OSW-1 is a promising lead compound for development of novel antitumor drugs. ${ }^{4,5}$

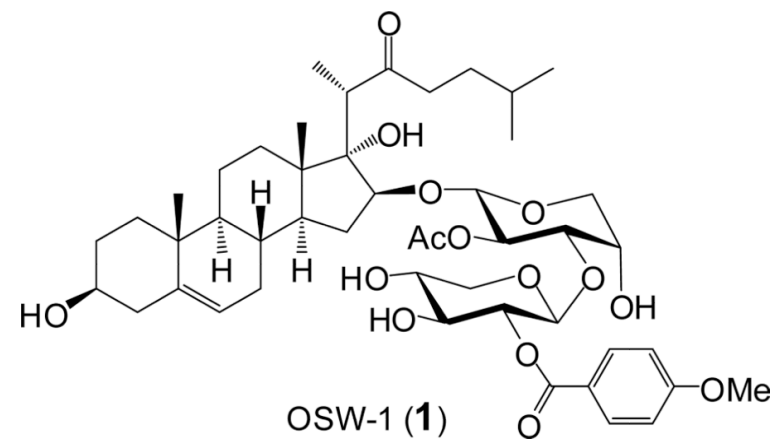

Owing to its interesting structure and highly potent anticancer activity, OSW-1 has been an attractive synthetic target for organic chemists. For example, $\mathrm{Yu}^{6,7}$ and $\mathrm{Jin}^{8,9}$ groups have independently developed total syntheses of OWS-1, while other groups have reported the synthesis of OSW-1 aglycone and other partial structures, ${ }^{10-13}$ as well as OSW-1 analogs. ${ }^{14-30}$ Structure-activity relationship studies on OSW-1 analogs have revealed new

*CORRESPONDING AUTHOR FOOTNOTE: To whom correspondence should be addressed. Phone: 313-577-2557; Fax: 313-577-8822,zwguo@chem.wayne.edu.

Supporting Information Available. Experimental procedures to prepare 15, 16 and 18, as well as the NMR spectra of 1, 2, 7, 10, 14, $16 \alpha, 16 \beta, 19,22$, and 23 . This material is available free of charge via the Internet at http://pubs.acs.org. 
compounds that have potent antitumor activity. ${ }^{7,19,21}$ In this paper, we have described a new, efficient and practical synthesis of OSW-1, which can be performed on gram scales.

\section{Results and Discussion}

\section{Synthesis of the aglycone}

Our overall synthetic design for OSW-1 was to first prepare the aglycone and the disaccharide moiety, which have different properties, separately and then couple them together to obtain the synthetic target. Scheme 1 has outlined the preparation of the aglycone, using commercially available (+)-dehydroisoandrosterone $\mathbf{3}$ as the starting material. In this synthesis, a key step was to introduce a side chain to the $C-17$, as described by $\mathrm{Yu}^{6,7}$ and Jin. ${ }^{8,9}$ For this purpose, we first added propanenitrile to 3 at $-78{ }^{\circ} \mathrm{C}$ by an aldol condensation reaction catalyzed by LDA to obtain an epimeric mixture 4 in an excellent yield upon recrystallization. As both isomers could be used in the next step, we did not try to separate them further. However, we discovered that, when the reaction was quenched at room temperature, instead of $-78{ }^{\circ} \mathrm{C}$, the yield of $\mathbf{4}$ was poor, while the starting material was recovered, suggesting that the retro-aldol condensation reaction was prominent at higher temperature. Further elongation of the side chain by refluxing 4 with a Grignard reagent in benzene proceeded smoothly, but the addition reaction was accompanied by $\beta$ elimination to give $\mathbf{5}$ as well as a small amount of $\mathbf{6}$ and $\mathbf{7}$ as an inseparable mixture. We have also tested some other reaction conditions, e.g., using THF or diethyl ether as the reaction solvent, but the reaction in benzene gave the best results. According to the literature, ${ }^{31} 5,6$ and 7 would reach an equilibrium under basic conditions to give the thermodynamically more stable $\mathbf{7}$ as the major product. Therefore, we treated the mixture of $\mathbf{5 , 6}$ and 7 with $\mathrm{NaOH}$ in $\mathrm{MeOH}$. The NMR spectrum of the newly formed mixture revealed 4:3:5 ratios of $\mathbf{5 , 6}$ and 7. Although these three compounds were inseparable on TLC or by silica gel column chromatography, fortunately, the desired product 7 could be separated from the other two isomers by recrystallization from hexane. Moreover, after $\mathbf{7}$ was collected, the mother liquid could be concentrated, and the mixture was treated with $\mathrm{NaOH}$ again to yield another crop of $\mathbf{7}$ upon recrystallization from hexane. This procedure was repeated another time to finally obtain $\mathbf{7}$ in a good yield (73\%). The stereochemistry of epimers 6 and 7 was determined through analysis of their ${ }^{1} \mathrm{H}$ NMR spectra. According to the literature, ${ }^{31}$ the proton NMR signal of $21-\mathrm{CH}_{3}$ in $\mathbf{6}$ appears at downfield $(\delta 1.25)$ compared to that of $21-\mathrm{CH}_{3}$ in $7(\delta 1.15)$. The configuration of 7 was further confirmed by comparing the physical data of its subsequent products with that of the same structures reported in the literature. For example, after selective protection of 3-OH in 7 by $t$-butyldimethylsilyl (TBS) via reacting with TBS chloride and imidazole in DMF and then protection of the $C-22$ carbonyl group by ethylene glycol to form a ketal, the product 9 gave ${ }^{1} \mathrm{H}$ and ${ }^{13} \mathrm{C}$ NMR spectra identical to that reported by $\mathrm{Yu}$ et al. ${ }^{6}$ Both reactions were very clean and gave excellent yields. Eventually, the key intermediate 9 was obtained from $\mathbf{3}$ in only 4 separate steps, in contrast to 7 to 9 steps described in the literature. ${ }^{6}$ In addition, the reactions were very reliable and the reaction products were easily purified through recrystallization, facilitating large scale synthesis.

Compound $\mathbf{9}$ was transformed into $\mathbf{2}$ in 3 steps as described in the literature. ${ }^{6,10}$ First, 9 was regioselectively dihydroxylated to afford $16 \alpha, 17 \alpha$-diol 10 in a moderate yield with the recovery of some starting material and the observation of some polar by-products which might be derived from excessive oxidation. The inversion of $C-16$ stereochemistry was conveniently realized after regioselective Swern oxidation of 16-OH using DMSO and oxalyl chloride and then reduction of the resultant ketone 11 by $\mathrm{NaBH}_{4}$ in the presence of $\mathrm{CeCl}_{3}$ to give 2 exclusively. Consequently, 2 was obtained from (+)-dehydroisoandrosterone in 7 steps and an overall yield of $15 \%$. 


\section{Synthesis of the disaccharide moiety}

Monosaccharides as glycosyl acceptors and donors employed in this synthesis were prepared

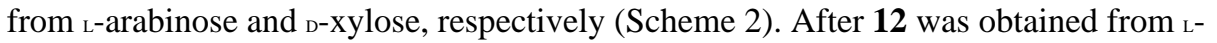
arabinose as reported, ${ }^{32}$ it was regioselectively $p$-methoxybenzxylated with the assist of dibutyltin complex to afford $\mathbf{1 3}$, which was directly subjected to acetolysis to give the desired glycosyl acceptor 14. In contrast to galactose derivatives in which 3-OH is usually more reactive than $4-\mathrm{OH}$, in $\mathbf{1 2}, 4-\mathrm{OH}$ was more reactive than $3-\mathrm{OH}$, probably because, as a pentose, arabinose has a less hindered 4-OH. Compound $\mathbf{1 4}$ had an acetyl group attached to its $2-\mathrm{OH}$, while its $4-\mathrm{OH}$ and $1-\mathrm{OH}$ groups were protected by a $p$-methoxybenzyl (PMB) group and an acetyl group, respectively. It was expected that its anomeric acetyl group could be selectively removed, after the desired disaccharide was constructed, to subsequently convert the disaccharide into a glycosyl donor used for glycosylation of the aglycone. Eventually, $\mathbf{1 4}$ was synthesized from L-arabinose on multigram scales in an overall yield of $56 \%$.

Monosaccharide donors 15 and 16 were prepared according to Jin's method ${ }^{9}$ with modified workup procedures. In brief, D-xylose was transformed into $\mathbf{1 5}$ through a series of reactions without isolation of the reaction intermediates, and only $\mathbf{1 5}$ was finally purified by column chromatography to get an overall yield of $74 \%$ on a multigram scale. Thereafter, $\mathbf{1 5}$ was converted to Schmidt donor $\mathbf{1 6}$ following oxidative deprotection of the anomeric center using $\mathrm{N}$-bromosuccinimide (NBS) and $\mathrm{H}_{2} \mathrm{O}$ and then trichloroacetimidation of the resultant hemiacetal. The $\alpha$ - and $\beta$-anomers of $\mathbf{1 6}$ were separable and both isomers were individually characterized, but their mixture was employed in subsequent glycosylation.

We first tried the glycosylation of $\mathbf{1 4}$ using $\mathbf{1 5}$ as glycosyl donor and $N$-iodosuccinimide (NIS) and triflic acid (TfOH) as promoter. Instead of the desired disaccharide, the reaction gave $\mathbf{1 7}$ as the major product with complete recovery of $\mathbf{1 4}$. This result indicated that $\mathbf{1 5}$ was activated by NIH/TfOH, but the resultant reactive intermediate reacted with the by-product of NIS, rather than 14, suggesting that the former might be more nucleophilic than the latter. To avoid this problem, we then used bromine as promoter in the presence, as well as in the absence, of silver triflate (AgOTf). This reaction also failed to yield the desired disaccharide; instead, $\mathbf{1 8}$ was obtained as the major product. These results suggest that $\mathbf{1 4}$ is a particularly poor glycosyl acceptor, which is consistent with the relative reactivity shown by the two hydroxyl groups in 12. Fortunately, the glycosylation of $\mathbf{1 4}$ with $\mathbf{1 6}$ as glycosyl donor went well to give $\mathbf{1 9}$ in a good yield and stereoselectivity, and the reaction was also proved to be very reliable. Finally, 19 was converted to glycosyl donor 21 as an $\alpha$ - and $\beta$ anomeric mixture upon selective removal of the anomeric acetyl group and then trichloroacetimidation of the resultant hemiacetal $\mathbf{2 0}$.

\section{Synthesis of OSW-1}

With both the aglycone $\mathbf{2}$ and the disaccharide donor $\mathbf{2 1}$ in hand, the finally assembly of OSW-1 was straightforward (Scheme 4). The glycosylation of $\mathbf{2}$ by $\mathbf{2 1}$ was achieved with trimethylsilyl triflate (TMSOTf) as promoter to produce the protected OSW-1 22. Global deprotection of $\mathbf{2 2}$ was accomplished in two separate steps. First, the TBS and ketal groups at $O-3$ and C-22 positions of the aglycone, respectively, were removed under mild acidic conditions. Next, the PMB groups on the disaccharide moiety of $\mathbf{2 3}$ were removed by 2,3dichloro-5,6-dicyanobenzoquinone (DDQ) oxidation to afford the synthetic target OSW-1 (1). The physical data of our final product were identical to the reported data of OSW-1., ${ }^{1,6,9}$

In summary, OSW-1 was synthesized from (+)-dehydroisoandrosterone 3 in 10 linear steps and an overall yield of $6.4 \%$, with new and efficient procedures developed to prepare the aglycone as well as the monosaccharide and disaccharide building blocks. This synthesis is 
highlighted by the reliability of all involved transformations and the simple workup procedures. For example, in the preparation of the aglycone and the monosaccharide building blocks, most intermediates were either purified through recrystallization or directly used in subsequent reactions without purification, which enabled large scale synthesis. Consequently, OSW-1 was obtained in gram scale. This new synthetic strategy is currently employed to prepare various derivatives of OSW-1 for studies of its structure-activity relationships and for exploration of novel anticancer therapeutics.

\section{Experimental}

\section{Compound $4 .{ }^{31}$}

To the solution of (+)-dehydroisoandrosterone $(3,3.06 \mathrm{~g}, 10.6 \mathrm{mmol})$ and propanenitrile (5 $\mathrm{mL}, 70 \mathrm{mmol})$ in $200 \mathrm{~mL}$ of THF was added LDA in THF $(20 \mathrm{~mL}, 40 \mathrm{mmol})$ at $-78{ }^{\circ} \mathrm{C}$. After the reaction mixture was stirred for another $30 \mathrm{~min}$, it was diluted with diethyl ether and then quenched with saturated aq. $\mathrm{NH}_{4} \mathrm{Cl}$ solution at $-78{ }^{\circ} \mathrm{C}$. The organic layer was separated and dried over anhydrous $\mathrm{Na}_{2} \mathrm{SO}_{4}$. After filtration and removal of the solvent, the residue was recrystallized from diethyl ether and hexane to give $4(3.5 \mathrm{~g}, 96 \%)$ as colorless crystals. ${ }^{1} \mathrm{H}$ NMR $\left(\mathrm{CDCl}_{3}, 400 \mathrm{MHz}\right): \delta 5.33(\mathrm{br}, 1 \mathrm{H}), 4.58-4.46(\mathrm{~m}, 1 \mathrm{H}), 2.84-2.70(\mathrm{q}, J=$ $6.8 \mathrm{~Hz}, 1 \mathrm{H}), 2.32-2.20(\mathrm{~m}, 2 \mathrm{H}), 2.04-1.83(\mathrm{~m}, 6 \mathrm{H}), 1.76-1.40(\mathrm{~m}, 12 \mathrm{H}), 1.35(\mathrm{~d}, J=6.8 \mathrm{~Hz}$, $3 \mathrm{H}), 1.18-1.10(\mathrm{~m}, 1 \mathrm{H}), 1.04(\mathrm{~s}, 3 \mathrm{H}), 0.94(\mathrm{~s}, 3 \mathrm{H})$. HR ESI MS: calcd for $\mathrm{C}_{22} \mathrm{H}_{33} \mathrm{NO}_{2}$ 343.2511, found $343.2507\left(\mathrm{M}^{+}\right)$.

\section{Compound 7.31}

To the solution of 4 (2.78 g, $8.1 \mathrm{mmol})$ in $200 \mathrm{~mL}$ of benzene was added freshly prepared 3methylbutylmagnesium bromide in benzene $(80 \mathrm{~mL}, 64 \mathrm{mmol})$. The reaction mixture was refluxed overnight. TLC indicated the complete consumption of starting materials. Then, the organic solvent was removed under reduced pressure, and $200 \mathrm{~mL}$ of aq. $\mathrm{HCl}$ solution $(1 \mathrm{~N})$ was added. After the mixture was stirred at rt overnight, it was extracted with diethyl ether. The combined organic layer was dried with anhydrous $\mathrm{Na}_{2} \mathrm{SO}_{4}$ and condensed. The residue was purified with a silica gel column briefly to afford an inseparable mixture of 5, 6 and $\mathbf{7}$ $(1.78 \mathrm{~g}, 55 \%)$. To a solution of $2.98 \mathrm{~g}$ of the mixture of $\mathbf{5 , 6}$ and 7 in $40 \mathrm{~mL}$ of $\mathrm{MeOH}$ and $12 \mathrm{~mL}$ of $\mathrm{H}_{2} \mathrm{O}$ was added $6 \mathrm{~g}$ of $\mathrm{NaOH}$. After the mixture was refluxed for $4 \mathrm{~h}, \mathrm{MeOH}$ was removed under reduced pressure. The remaining mixture was extracted with diethyl ether. The combined organic layer was dried with anhydrous $\mathrm{Na}_{2} \mathrm{SO}_{4}$ and condensed. The residue was then dissolved in $100 \mathrm{~mL}$ of hot hexane for recrystallization to get $1.10 \mathrm{~g}$ of the desired product 7. The mother liquid was condensed and the residue was dissolved in $\mathrm{MeOH}$ and $\mathrm{H}_{2} \mathrm{O}$ and treated with $\mathrm{NaOH}$ again. Following the same work up and recrystallization protocol, another crop of pure 7 was obtained. After repeating this procedure for another time, a total of $2.20 \mathrm{~g}$ of 7 was obtained $(73 \%) .[\alpha]_{\mathrm{D}}^{25}:+11.0\left(c 1.0, \mathrm{CH}_{2} \mathrm{Cl}_{2}\right) .{ }^{1} \mathrm{H}$ NMR $\left(\mathrm{CDCl}_{3}, 400 \mathrm{MHz}\right): \delta 5.37(\mathrm{~s}, 2 \mathrm{H}), 3.35(\mathrm{~m}, 1 \mathrm{H}), 3.20(\mathrm{q}, J=6.8 \mathrm{~Hz}, 1 \mathrm{H}), 2.53-2.45(\mathrm{~m}$, $1 \mathrm{H}), 2.39-2.20(\mathrm{~m}, 3 \mathrm{H}), 2.18-1.80(\mathrm{~m}, 7 \mathrm{H}), 1.70-1.24(\mathrm{~m}, 13 \mathrm{H}), 1.15(\mathrm{~d}, J=6.8 \mathrm{~Hz}, 3 \mathrm{H})$, 1.14-0.96 (m, 4H), 0.90-0.80 (m, 7H). ${ }^{13} \mathrm{C} \mathrm{NMR}\left(\mathrm{CDCl}_{3}, 100 \mathrm{MHz}\right): \delta 154.5,141.3,125.4$, 121.6, 71.8, 57.3, 50.8, 47.5, 45.9, 42.5, 38.5, 37.4, 36.9, 34.9, 33.3, 31.8, 31.7, 31.5, 30.8, 27.8, 22.7, 22.5, 21.0, 19.5, 17.1, 16.5. EI MS: calcd for $\mathrm{C}_{27} \mathrm{H}_{42} \mathrm{O}_{2} 398.3$, found $399.5(\mathrm{M}+$ $\left.\mathrm{H}^{+}\right)$.

\section{Compound $8 .^{6}$}

To the solution of $7(1.03 \mathrm{~g}, 2.58 \mathrm{mmol})$ and imidazole $(0.45 \mathrm{~g}, 7.76 \mathrm{mmol})$ in $20 \mathrm{~mL}$ of $\mathrm{CH}_{2} \mathrm{Cl}_{2}$ was added $\mathrm{TBSCl}(0.58 \mathrm{~g}, 3.87 \mathrm{mmol})$ at $\mathrm{rt}$. After the reaction mixture was stirred for $2 \mathrm{~h}$, aq. $\mathrm{HCl}$ solution $(1 \mathrm{~N})$ was added to quench the reaction, and the reaction mixture was extracted with diethyl ether. The combined organic layer was washed with saturated 
$\mathrm{NaHCO}_{3}$, dried over anhydrous $\mathrm{Na}_{2} \mathrm{SO}_{4}$, and then condensed. The residue was purified by column chromatography to give $\mathbf{8}(1.37 \mathrm{~g}, 99 \%)$ as a white solid. $[\alpha]_{\mathrm{D}}^{25}:+18.6(c 1.0$, $\left.\mathrm{CH}_{2} \mathrm{Cl}_{2}\right) .{ }^{1} \mathrm{H}$ NMR $\left(\mathrm{CDCl}_{3}, 200 \mathrm{MHz}\right): \delta 5.34(\mathrm{br}, 2 \mathrm{H}), 3.55-3.40(\mathrm{~m}, 1 \mathrm{H}), 3.18(\mathrm{q}, J=6.8$ $\mathrm{Hz}, 1 \mathrm{H}), 2.58-1.80(\mathrm{~m}, 7 \mathrm{H}), 1.80-1.40(\mathrm{~m}, 17 \mathrm{H}), 1.15(\mathrm{~d}, J=6.8 \mathrm{~Hz}, 3 \mathrm{H}), 1.09(\mathrm{~s}, 6 \mathrm{H}) .{ }^{13} \mathrm{C}$ NMR $\left(\mathrm{CDCl}_{3}, 50 \mathrm{MHz}\right): \delta 211.6,154.4,141.9,125.2,120.9,72.6,57.2,50.8,47.4,45.7$, $42.9,38.3,37.4,36.9,34.7,33.1,32.1,31.6,31.3,30.7,27.7,25.0,25.7,22.6,22.3,20.8$, 19.4, 18.3, 16.9, 16.3, 4.5. EI MS: calcd for $\mathrm{C}_{33} \mathrm{H}_{56} \mathrm{O}_{2} \mathrm{Si} 512.4$, found $513.7\left(\mathrm{M}+\mathrm{H}^{+}\right)$.

\section{Compound 9.6}

To the solution of $8(1.39 \mathrm{~g}, 2.71 \mathrm{mmol})$, ethylene glycol $(0.5 \mathrm{~mL}, 8.94 \mathrm{mmol})$ and triethyl orthoformate $(0.5 \mathrm{~mL}, 3.00 \mathrm{mmol})$ in $20 \mathrm{~mL}$ of benzene was added PTS $\cdot \mathrm{H}_{2} \mathrm{O}(20 \mathrm{mg}, 0.10$ $\mathrm{mmol})$. The mixture was stirred at $\mathrm{rt}$ for 2 days and then quenched with saturated aq. $\mathrm{NaHCO}_{3}$ solution. The mixture was extracted with $\mathrm{Et}_{2} \mathrm{O}$. After the organic layer was dried over anhydrous $\mathrm{Na}_{2} \mathrm{SO}_{4}$ and condensed, the product was purified by column chromatography to give 9 (1.46 g, 96\%) as a white solid. $[\alpha]_{\mathrm{D}}^{25}:+38.4\left(c 1.0, \mathrm{CH}_{2} \mathrm{Cl}_{2}\right) .{ }^{1} \mathrm{H}$ NMR ( $\left.\mathrm{CDCl}_{3}, 200 \mathrm{MHz}\right): \delta 5.66(\mathrm{br}, 1 \mathrm{H}), 5.35(\mathrm{br}, 1 \mathrm{H}), 3.96(\mathrm{~s}, 4 \mathrm{H}), 3.60-3.40(\mathrm{~m}, 1 \mathrm{H})$, $2.44(\mathrm{q}, J=7.0 \mathrm{~Hz}, 1 \mathrm{H}), 2.32-2.18(\mathrm{~m}, 3 \mathrm{H}), 2.18-1.90(\mathrm{~m}, 2 \mathrm{H}), 1.90-1.38(\mathrm{~m}, 21 \mathrm{H})$, $1.38-1.10(\mathrm{~m}, 6 \mathrm{H}), 1.10-0.92(\mathrm{~m}, 9 \mathrm{H}), 0.92-0.76(\mathrm{~m}, 11 \mathrm{H}) .{ }^{13} \mathrm{C} \mathrm{NMR}\left(\mathrm{CDCl}_{3}, 75 \mathrm{MHz}\right): \delta$ 156.6, 141.1, 124.0, 121.6, 113.9, 71.7, 65.9, 65.3, 57.3, 47.5, 42.4, 39.2, 37.2, 36.8, 34.9, $34.0,32.5,31.7,31.4,30.7,28.4,22.7,20.9,19.4,17.4,15.7,-4.5$. EI MS: calcd for $\mathrm{C}_{35} \mathrm{H}_{60} \mathrm{O}_{3} \mathrm{Si}$ 556.4, found $557.6\left(\mathrm{M}+\mathrm{H}^{+}\right)$.

\section{Compound $10^{6}$}

To the solution of $9(0.40 \mathrm{~g}, 0.71 \mathrm{mmol})$ in $10 \mathrm{~mL}$ of diethyl ether and $0.5 \mathrm{~mL}$ of pyridine was added $\mathrm{OsO}_{4}(0.35 \mathrm{~g}, 1.38 \mathrm{mmol})$ at $-60^{\circ} \mathrm{C}$. Then, the reaction mixture was warmed to $\mathrm{rt}$ and stirred for $3 \mathrm{~h}$. The reaction was quenched with saturated aq. $\mathrm{NaHSO}_{3}$ solution and the suspension was stirred overnight. The mixture was extracted with ethyl acetate, and the combined organic layer was dried over anhydrous $\mathrm{Na}_{2} \mathrm{SO}_{4}$. After concentration, the residue was purified by column chromatography to give $\mathbf{1 0}(0.21 \mathrm{~g}, 50 \%)$ as a white solid. [ $\alpha]_{\mathrm{D}}^{25}$ : $56.67\left(c 0.99 \mathrm{CHCl}_{3}\right) .{ }^{1} \mathrm{H} \mathrm{NMR}\left(\mathrm{CDCl}_{3}, 300 \mathrm{MHz}\right): \delta 5.30(1 \mathrm{H}, \mathrm{d}, J=4.2 \mathrm{~Hz}), 4.28(1 \mathrm{H}$, $\mathrm{m}), 3.97(4 \mathrm{H}, \mathrm{m}), 3.47(1 \mathrm{H}, \mathrm{m}), 1.12(3 \mathrm{H}, \mathrm{d}, J=7.0 \mathrm{~Hz}), 0.98(3 \mathrm{H}, \mathrm{s}), 0.88(9 \mathrm{H}, \mathrm{s}), 0.77$ $(3 \mathrm{H}, \mathrm{s}), 0.04(6 \mathrm{H}, \mathrm{s}) .{ }^{13} \mathrm{C} \mathrm{NMR}\left(\mathrm{CDCl}_{3}, 75 \mathrm{MHz}\right): \delta 141.5,120.9,115.7,82.4,75.9,72.6$, 65.8, 64.4, 49.9, 49.6, 48.0, 45.3, 42.8, 37.2, 36.5, 33.3, 32.8, 32.1, 31.8, 31.3, 29.7, 28.1, 25.9, 22.7, 20.4, 19.4, 18.2, 14.3, 13.1, -4.6. EI MS: calcd for $\mathrm{C}_{35} \mathrm{H}_{62} \mathrm{O}_{5} \mathrm{Si} 590.4$, found $591.5\left(\mathrm{M}+\mathrm{H}^{+}\right)$.

\section{Compound 11. 6}

After the solution of oxalyl chloride $(0.11 \mathrm{~mL})$ and DMSO $(0.18 \mathrm{~mL})$ in $2 \mathrm{~mL}$ of $\mathrm{CH}_{2} \mathrm{Cl}_{2}$ was stirred at $-50{ }^{\circ} \mathrm{C}$ for $15 \mathrm{~min}$, a solution of $\mathbf{1 0}(0.26 \mathrm{~g}, 0.44 \mathrm{mmol})$ in $\mathrm{CH}_{2} \mathrm{Cl}_{2}(5 \mathrm{~mL})$ was added. The mixture was stirred at $-50^{\circ} \mathrm{C}$ for another $15 \mathrm{~min}$, and then $1.0 \mathrm{~mL}$ of triethylamine was added. After the reaction mixture was warmed to rt slowly, the product was extracted with $\mathrm{CH}_{2} \mathrm{Cl}_{2}$, dried with anhydrous $\mathrm{Na}_{2} \mathrm{SO}_{4}$, and condensed. The residue was purified by column chromatography to give $\mathbf{1 1}(0.24 \mathrm{~g}, 92 \%)$ as a white solid. $[\alpha]_{\mathrm{D}}^{25}:-150(c$ $\left.1.13, \mathrm{CHCl}_{3}\right) .{ }^{1} \mathrm{H} \mathrm{NMR}\left(\mathrm{CDCl}_{3}, 300 \mathrm{MHz}\right): \delta 5.30(1 \mathrm{H}, \mathrm{d}, J=5.2 \mathrm{~Hz}), 4.05-3.90(4 \mathrm{H}, \mathrm{m})$, $3.47(1 \mathrm{H}, \mathrm{m}), 2.72(1 \mathrm{H}, \mathrm{q}, J=7.4 \mathrm{~Hz}), 1.02(3 \mathrm{H}, \mathrm{s}), 1.01(3 \mathrm{H}, \mathrm{d}, J=7.4 \mathrm{~Hz}), 0.87(9 \mathrm{H}, \mathrm{s})$, $0.05(6 \mathrm{H}, \mathrm{s}) .{ }^{13} \mathrm{C} \mathrm{NMR}\left(\mathrm{CDCl}_{3}, 75 \mathrm{MHz}\right): \delta 215.5,141.6,120.7,115.4,85.4,72.5,63.4$, 63.3, 49.5, 46.9, 45.4, 42.7, 41.2, 37.2, 37.1, 36.7, 32.7, 32.2, 32.0, 30.8, 30.2, 28.3, 25.9, 22.7, 22.4, 20.1, 19.4, 18.2, 15.0, 14.3, -4.6. EI MS: calcd for $\mathrm{C}_{35} \mathrm{H}_{60} \mathrm{O}_{5} \mathrm{Si} 588.4$, found $589.7\left(\mathrm{M}+\mathrm{H}^{+}\right)$. 


\section{Compound 2.8}

To a solution of $\mathbf{1 1}(0.40 \mathrm{~g}, 0.07 \mathrm{mmol})$ in $50 \mathrm{~mL}$ of THF was added $0.80 \mathrm{~g}$ of $\mathrm{CeCl}_{3} \cdot 7 \mathrm{H}_{2} \mathrm{O}$ and $0.40 \mathrm{~g}$ of $\mathrm{NaBH}_{4}$ at $0{ }^{\circ} \mathrm{C}$. The reaction mixture was stirred at $0{ }^{\circ} \mathrm{C}$ for $4 \mathrm{~h}$ and then extracted with $\mathrm{CH}_{2} \mathrm{Cl}_{2}$. The organic layer was dried and concentrated, and the residue was purified by column chromatography to provide $2(0.36 \mathrm{~g}, 90 \%)$ as a white solid. $[\alpha]_{\mathrm{D}}^{25}-36(c$ 1.0, $\left.\mathrm{CHCl}_{3}\right) .{ }^{1} \mathrm{H} \mathrm{NMR}\left(\mathrm{CDCl}_{3}, 400 \mathrm{MHz}\right): \delta 5.30(\mathrm{~d}, 1 \mathrm{H}, J=4.2 \mathrm{~Hz}, \mathrm{H}-6), 4.05(\mathrm{~m}, 1 \mathrm{H})$, 3.94-4.07 (m, $4 \mathrm{H}), 3.48(\mathrm{~m}, 1 \mathrm{H}), 2.59(\mathrm{q}, 1 \mathrm{H}, J=7.5 \mathrm{~Hz}), 1.18(\mathrm{~s}, 3 \mathrm{H}), 1.02(\mathrm{~d}, 3 \mathrm{H}, J=$ $7.5 \mathrm{~Hz}), 0.90$ (s, $3 \mathrm{H}), 0.87(\mathrm{~s}, 9 \mathrm{H}), 0.89,0.87(2 \mathrm{~d}, 6 \mathrm{H}, J=6.5 \mathrm{~Hz}), 0.02(\mathrm{~s}, 6 \mathrm{H}) .{ }^{13} \mathrm{C}$ NMR $\left(\mathrm{CDCl}_{3}, 100 \mathrm{MHz}\right): \delta 141.6,121.3,116.7,92.5,87.0,81.8,72.8,64.3,63.0,49.8,48.1$, 48.0, 43.0, 37.5, 36.7, 36.1, 34.1, 33.3, 33.0, 32.9, 32.3, 32.1, 28.5, 26.1, 22.9, 22.5, 20.9, 19.6, 18.4, 112.7, 12.2, -4.4. HR FAB MS: calcd for $\mathrm{C}_{35} \mathrm{H}_{61} \mathrm{O}_{5} \mathrm{Si}\left(\mathrm{M}-\mathrm{H}^{+}\right) 589.4288$, found 589.4250 .

\section{Compound 14}

A mixture of $12(5.55 \mathrm{~g}, 26.9 \mathrm{mmol})$ and $\mathrm{Bu}_{2} \mathrm{SnO}(6.72 \mathrm{~g}, 27 \mathrm{mmol})$ in $100 \mathrm{~mL}$ of toluene was refluxed with azeotropic removal of $\mathrm{H}_{2} \mathrm{O}$ for $2 \mathrm{~h}$. The reaction mixture was concentrated under reduced pressure. To the residue were added DMF $(50 \mathrm{~mL}), \mathrm{CsF}(7.6 \mathrm{~g}$, $50 \mathrm{mmol}), \mathrm{KI}(6 \mathrm{~g}, 40 \mathrm{mmol})$ and $p$-methoxylbenzyl chloride $(4.38 \mathrm{~mL}, 32 \mathrm{mmol})$ at $0{ }^{\circ} \mathrm{C}$. The mixture was stirred at rt overnight and then diluted with $\mathrm{CH}_{2} \mathrm{Cl}_{2}$. The organic phase was washed with brine, dried over $\mathrm{Na}_{2} \mathrm{SO}_{4}$, and concentrated to get 13 . The crude product 13 was dissolved in $50 \mathrm{~mL}$ of $\mathrm{AcOH}$, stirred at $\mathrm{rt}$ for $1 \mathrm{~h}$, and then concentrated under reduced pressure. The residue was dissolved in $\mathrm{CH}_{2} \mathrm{Cl}_{2}$ and washed with brine, dried over $\mathrm{Na}_{2} \mathrm{SO}_{4}$, and concentrated. Flash column chromatography of the product gave $\mathbf{1 4}$ as colorless syrup $(6.0 \mathrm{~g}, 63 \%) .[\alpha]_{\mathrm{D}}^{25}+51.2\left(c 1.0, \mathrm{CHCl}_{3}\right) .{ }^{1} \mathrm{H} \mathrm{NMR}\left(\mathrm{CDCl}_{3}, 400 \mathrm{MHz}\right): 7.26(\mathrm{~d}, J=8.8 \mathrm{~Hz}$, $2 \mathrm{H}), 6.88(\mathrm{~d}, J=8.8 \mathrm{~Hz}, 2 \mathrm{H}), 5.58(\mathrm{~d}, J=6.4 \mathrm{~Hz}, 1 \mathrm{H}), 5.10(\mathrm{t}, J=6.4 \mathrm{~Hz}, 1 \mathrm{H}), 4.66(\mathrm{~d}, J=$ $11.2 \mathrm{~Hz}, 1 \mathrm{H}), 4.48(\mathrm{~d}, J=11.2 \mathrm{~Hz}, 1 \mathrm{H}), 4.08(\mathrm{dd}, J=13.2,3.2 \mathrm{~Hz}, 1 \mathrm{H}), 3.80(\mathrm{~s}, 3 \mathrm{H}), 3.75$ (br, $2 \mathrm{H}), 3.52(\mathrm{~d}, \mathrm{~J}=13.2 \mathrm{~Hz}, 1 \mathrm{H}), 2.09(\mathrm{~s}, 3 \mathrm{H}), 2.08(\mathrm{~s}, 3 \mathrm{H}) .{ }^{13} \mathrm{C} \mathrm{NMR}\left(\mathrm{CDCl}_{3}, 100 \mathrm{MHz}\right)$ : 170.4, 169.7, 159.8, 129.8, 129.4, 114.2, 92.2, 74.1, 71.5, 71.4, 70.7, 62.4, 55.5, 21.2, 21.1. ESI MS: calc. for $\mathrm{C}_{17} \mathrm{H}_{22} \mathrm{O}_{8} 354.1$, found $377.0\left(\mathrm{M}+\mathrm{Na}^{+}\right)$; HR EI MS: calcd for $\mathrm{C}_{17} \mathrm{H}_{22} \mathrm{O}_{8}$ 354.1315, found $354.1324\left(\mathrm{M}^{+}\right)$.

\section{Disacharide 19}

After a mixture of $\mathbf{1 6}(13.4 \mathrm{~g}, 20 \mathrm{mmol}), \mathbf{1 4}(3.55 \mathrm{~g}, 10 \mathrm{mmol})$ and $4 \AA \mathrm{AS}(5.0 \mathrm{~g})$ in dry $\mathrm{CH}_{2} \mathrm{Cl}_{2}(50 \mathrm{~mL})$ was stirred at $\mathrm{rt}$ for $3 \mathrm{~h}$ and then cooled to $-15{ }^{\circ} \mathrm{C}, \mathrm{BF}_{3} \cdot \mathrm{Et}_{2} \mathrm{O}(2 \mathrm{mmol}$, $10 \%$ ) was added. The reaction mixture was stirred at -15 to $-10{ }^{\circ} \mathrm{C}$ for another $2 \mathrm{~h}$, and ${ }^{1} \mathrm{H}$ NMR spectrum of the mixture showed the completion of reaction. $\mathrm{Et}_{3} \mathrm{~N}(1.0 \mathrm{~mL})$ was added to quench the reaction, and the mixture was filtered off to remove molecular sieves. The filtrate was combined and concentrated under reduced pressure, and the residue was purified by silica gel column chromatography to afford $19(6.9 \mathrm{~g}, 80 \%)$ as a white foamy solid. $[\alpha]_{\mathrm{D}}^{25}$ $+6.6\left(c\right.$ 1.0, $\left.\mathrm{CHCl}_{3}\right) .{ }^{1} \mathrm{H} \mathrm{NMR}\left(\mathrm{CDCl}_{3}, 500 \mathrm{MHz}\right): 7.92(\mathrm{~d}, J=9.0 \mathrm{~Hz}, 2 \mathrm{H}), 7.26(\mathrm{~d}, J=8.5$ $\mathrm{Hz}, 2 \mathrm{H}), 7.24(\mathrm{~d}, J=9.0 \mathrm{~Hz}, 2 \mathrm{H}), 7.09(\mathrm{~d}, J=9.0 \mathrm{~Hz}, 2 \mathrm{H}), 6.87(\mathrm{~d}, J=9.0 \mathrm{~Hz}, 2 \mathrm{H}), 6.86(\mathrm{~d}$, $J=9.0 \mathrm{~Hz}, 2 \mathrm{H}), 6.84(\mathrm{~d}, J=8.5 \mathrm{~Hz}, 2 \mathrm{H}), 6.67(\mathrm{~d}, J=8.5 \mathrm{~Hz}, 2 \mathrm{H}), 5.53(\mathrm{~d}, J=5.5 \mathrm{~Hz}, 1 \mathrm{H})$, $5.20(\mathrm{t}, J=7.5 \mathrm{~Hz}, 1 \mathrm{H}), 5.17(\mathrm{t}, J=7.5 \mathrm{~Hz}, 1 \mathrm{H}), 4.70(\mathrm{~d}, J=6.0 \mathrm{~Hz}, 1 \mathrm{H}), 4.66(\mathrm{~d}, J=11.5$ $\mathrm{Hz}, 2 \mathrm{H}), 4.63(\mathrm{~d}, J=11.5 \mathrm{~Hz}, 1 \mathrm{H}), 4.62(\mathrm{~d}, J=11.5 \mathrm{~Hz}, 1 \mathrm{H}), 4.58(\mathrm{~d}, J=11.5 \mathrm{~Hz}, 1 \mathrm{H}), 4.53$ $(\mathrm{d}, J=11.5 \mathrm{~Hz}, 1 \mathrm{H}), 3.98(\mathrm{dd}, J=7.0,4.5 \mathrm{~Hz}, 1 \mathrm{H}), 3.92(\mathrm{dd}, J=7.5,6.0 \mathrm{~Hz}, 1 \mathrm{H}), 3.86(\mathrm{~s}$, $3 \mathrm{H}), 3.81(\mathrm{~s}, 3 \mathrm{H}), 3.79(\mathrm{~s}, 3 \mathrm{H}), 3.72(\mathrm{~s}, 3 \mathrm{H}), 3.50(\mathrm{dd}, J=12.5,2.5 \mathrm{~Hz}, 1 \mathrm{H}), 3.27-3.39(\mathrm{~m}$, 2H). ${ }^{13} \mathrm{C} \mathrm{NMR}\left(\mathrm{CDCl}_{3}, 100 \mathrm{MHz}\right): 169.9,169.2,164.9,163.7,159.6,159.4,159.3,132.1$, 130.5, 130.3, 129.9, 129.8, 122.5, 114.1, 113.9, 113.8, 102.0, 95.0, 92.2, 79.2, 76.8, 73.9, 72.8, 72.0, 71.8, 69.9, 63.1, 55.6, 55.5, 55.3, 21.0, 20.8. ESI MS: calcd for $\mathrm{C}_{46} \mathrm{H}_{52} \mathrm{O}_{16}$ 
860.3, found $883.3\left(\mathrm{M}+\mathrm{Na}^{+}\right), 899.3\left(\mathrm{M}+\mathrm{K}^{+}\right)$; HR EI MS: calcd for $\mathrm{C}_{46} \mathrm{H}_{52} \mathrm{O}_{16} 860.3255$, found $860.3267\left(\mathrm{M}^{+}\right)$.

\section{Protected OSW-1 (22)}

To a solution of compound $\mathbf{1 9}(3.45 \mathrm{~g}, 4.0 \mathrm{mmol})$ in THF ( $40 \mathrm{~mL})$ was added benzyl amine (4 mL). After the reaction mixture was stirred at rt overnight, it was diluted with $\mathrm{CH}_{2} \mathrm{Cl}_{2}$. The organic layer was sequentially washed with aq. $\mathrm{HCl}$ solution $(1 \mathrm{~N})$ and $\mathrm{H}_{2} \mathrm{O}$ and then dried over $\mathrm{Na}_{2} \mathrm{SO}_{4}$. The solvent was removed under reduced pressure, and the product was purified by silica gel column chromatography to give an $\alpha$ - and $\beta$-anomeric mixture of $\mathbf{2 0}$ as colorless syrup. To a solution of $\mathbf{2 0}$ in dry $\mathrm{CH}_{2} \mathrm{Cl}_{2}(20 \mathrm{~mL})$ was added trichloroacetonitrile $(1.0 \mathrm{~mL})$ and DBU (2 drops), and the mixture was stirred at $\mathrm{rt}$ overnight before the solvent was removed under reduced pressure. The residue was purified by flash column chromatography on a $\mathrm{Et}_{3} \mathrm{~N}$ deactivated silica gel column to afford $\mathbf{2 1}(2.87 \mathrm{~g})$ which was directly applied to the next step of synthesis. A solution of $21(1.5 \mathrm{~g}, 1.6 \mathrm{mmol}), \mathbf{2}(0.69 \mathrm{~g}$, $1.1 \mathrm{mmol})$ and $4 \AA \mathrm{MS}(1.0 \mathrm{~g})$ in dry $\mathrm{CH}_{2} \mathrm{Cl}_{2}(10 \mathrm{~mL})$ was stirred at $\mathrm{rt}$ for $3 \mathrm{~h}$. After the mixture was cooled to $-20{ }^{\circ} \mathrm{C}$, TMSOTf $(10.6 \mu \mathrm{L}, 0.055 \mathrm{mmol})$ was added. The reaction mixture was stirred at -15 to $-10{ }^{\circ} \mathrm{C}$ for $4 \mathrm{~h}$ and then quenched with $\mathrm{Et}_{3} \mathrm{~N}(0.3 \mathrm{~mL})$. After the reaction solution was filtered off to remove molecular sieves and the filtrate was condensed under reduced pressure, the residue was purified by flash column chromatography on a $\mathrm{Et}_{3} \mathrm{~N}$ deactivated silica gel column to afford $22(0.58 \mathrm{~g}, 58 \%)$ as a white foamy solid, with the recovery of some $2(0.25 \mathrm{~g}) . \mathbf{2 2}$ : $[\alpha]_{\mathrm{D}}^{25}-19.2\left(c 1.0, \mathrm{CHCl}_{3}\right) .{ }^{1} \mathrm{H}$ NMR $\left(\mathrm{CDCl}_{3}, 500 \mathrm{MHz}\right): 7.96(\mathrm{~d}, J=9.2 \mathrm{~Hz}, 2 \mathrm{H}), 7.26(\mathrm{~d}, J=8.8 \mathrm{~Hz}, 2 \mathrm{H}), 7.25(\mathrm{~d}, J=8.8$ $\mathrm{Hz}, 2 \mathrm{H}), 7.16(\mathrm{~d}, J=8.8 \mathrm{~Hz}, 2 \mathrm{H}), 6.81(\mathrm{~d}, J=9.2 \mathrm{~Hz}, 2 \mathrm{H}), 6.80(\mathrm{~d}, J=8.0 \mathrm{~Hz}, 2 \mathrm{H}), 6.79(\mathrm{~d}$, $J=8.8 \mathrm{~Hz}, 2 \mathrm{H}), 6.73(\mathrm{~d}, J=8.0 \mathrm{~Hz}, 2 \mathrm{H}), 5.25(\mathrm{br}, 2 \mathrm{H}), 5.09(\mathrm{br}, 1 \mathrm{H}), 5.02(\mathrm{br}, 1 \mathrm{H}), 4.76(\mathrm{~d}$, $J=11.2 \mathrm{~Hz}, 1 \mathrm{H}), 4.11(\mathrm{~m}, 2 \mathrm{H}), 3.84(\mathrm{~s}, 3 \mathrm{H}), 3.78(\mathrm{~s}, 3 \mathrm{H}), 3.76(\mathrm{~s}, 3 \mathrm{H}), 3.72(\mathrm{~s}, 3 \mathrm{H}), 3.07(\mathrm{q}$, $J=7.2 \mathrm{~Hz}, 1 \mathrm{H}), 2.64(\mathrm{q}, J=7.6 \mathrm{~Hz}, 1 \mathrm{H}), 1.98(\mathrm{~s}, 3 \mathrm{H}), 1.14(\mathrm{~d}, J=7.6 \mathrm{~Hz}, 3 \mathrm{H}), 0.92(\mathrm{~s}, 3 \mathrm{H})$, $0.89(\mathrm{~s}, 9 \mathrm{H}), 0.85(\mathrm{~s}, 3 \mathrm{H}), 0.67(\mathrm{~d}, J=6.8 \mathrm{~Hz}, 3 \mathrm{H}), 0.57(\mathrm{~d}, J=5.6 \mathrm{~Hz}, 3 \mathrm{H}), 0.05(\mathrm{~s}$, $6 \mathrm{H}) .{ }^{13} \mathrm{C} \mathrm{NMR}\left(\mathrm{CDCl}_{3}, 125 \mathrm{MHz}\right): 169.2,165.2,164.1,163.7,159.3,159.1,141.2,132.3$, 130.6, 130.4, 130.3, 129.8, 129.5, 128.8, 122.3, 121.6, 116.6, 113.9, 113.8, 113.7, 101.2, 92.1, 87.4, 72.9, 71.6, 71.3, 64.6, 62.8, 55.6, 55.5, 55.3, 49.9, 48.3, 48.2, 46.1, 43.0, 37.5, 36.6, 35.4, 33.7, 32.6, 32.5, 32.3, 31.9, 31.8, 29.9, 28.4, 26.2, 22.9, 22.7, 22.1, 21.2, 20.9,

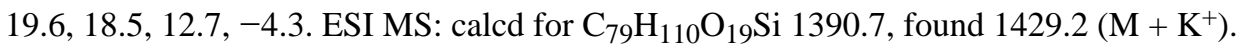

\section{Partially protected OSW-1 (23)}

After a solution of $22(0.55 \mathrm{~g}, 0.39 \mathrm{mmol})$ in a mixture of $\mathrm{AcOH}$ and $\mathrm{H}_{2} \mathrm{O}(1: 5,5 \mathrm{~mL})$ was stirred at $70^{\circ} \mathrm{C}$ for $2 \mathrm{~h}$, the solvent was removed under reduced pressure. The residue was purified by flash column chromatography to give $23(0.44 \mathrm{~g}, 90 \%)$ as a white solid. [ $\alpha]_{\mathrm{D}}^{25}$ $-22.8\left(c 1.0, \mathrm{CHCl}_{3}\right) .{ }^{1} \mathrm{H} \mathrm{NMR}\left(\mathrm{CDCl}_{3}, 400 \mathrm{MHz}\right): 7.97(\mathrm{~d}, J=9.2 \mathrm{~Hz}, 2 \mathrm{H}), 7.24(\mathrm{~d}, J=$ $8.8 \mathrm{~Hz}, 2 \mathrm{H}), 7.21(\mathrm{~d}, J=8.4 \mathrm{~Hz}, 2 \mathrm{H}), 7.16(\mathrm{~d}, J=8.8 \mathrm{~Hz}, 2 \mathrm{H}), 6.86(\mathrm{~d}, J=8.8 \mathrm{~Hz}, 2 \mathrm{H}), 6.83$ $(\mathrm{d}, J=8.4 \mathrm{~Hz}, 2 \mathrm{H}), 6.82(\mathrm{~d}, J=8.4 \mathrm{~Hz}, 2 \mathrm{H}), 6.69(\mathrm{~d}, J=8.8 \mathrm{~Hz}, 2 \mathrm{H}), 5.30(\mathrm{br}, 1 \mathrm{H}), 5.18(\mathrm{t}$, $J=4.8 \mathrm{~Hz}, 1 \mathrm{H}), 4.79(\mathrm{br}, 2 \mathrm{H}), 4.67(\mathrm{~d}, J=11.2 \mathrm{~Hz}, 1 \mathrm{H}), 4.63(\mathrm{~d}, J=12.4 \mathrm{~Hz}, 1 \mathrm{H}), 4.58(\mathrm{~d}$, $J=11.2 \mathrm{~Hz}, 1 \mathrm{H}), 4.53(\mathrm{~d}, J=11.6 \mathrm{~Hz}, 1 \mathrm{H}), 4.52(\mathrm{~d}, J=11.2 \mathrm{~Hz}, 1 \mathrm{H}), 4.49(\mathrm{~d}, J=11.2 \mathrm{~Hz}$, $1 \mathrm{H}), 4.29$ (br, 1H), $4.21(\mathrm{~d}, J=4.0 \mathrm{~Hz}, 1 \mathrm{H}), 3.94(\mathrm{dd}, J=11.2,7.6 \mathrm{~Hz}, 1 \mathrm{H}), 3.86(\mathrm{~s}, 3 \mathrm{H})$, $3.80(\mathrm{~s}, 3 \mathrm{H}), 3.78(\mathrm{~s}, 3 \mathrm{H}), 3.72(\mathrm{~s}, 3 \mathrm{H}), 3.59(\mathrm{q}, J=4.0 \mathrm{~Hz}, 1 \mathrm{H}), 3.52(\mathrm{~m}, 1 \mathrm{H}), 3.42(\mathrm{~m}, 2 \mathrm{H})$, $3.03(\mathrm{q}, J=7.2 \mathrm{~Hz}, 1 \mathrm{H}), 1.89$ (s, 3H), $1.13(\mathrm{~d}, J=7.6 \mathrm{~Hz}, 3 \mathrm{H}), 0.95$ (s, 3H), 0.79 (s, 3H), $0.74(\mathrm{~d}, J=6.8 \mathrm{~Hz}, 3 \mathrm{H}), 0.73(\mathrm{~d}, J=6.8 \mathrm{~Hz}, 3 \mathrm{H}) .{ }^{13} \mathrm{C} \mathrm{NMR}\left(\mathrm{CDCl}_{3}, 100 \mathrm{MHz}\right): 169.1$, 164.9, 163.7, 159.4, 159.2, 159.1, 140.5, 139.6, 132.1, 130.6, 130.3, 130.2, 129.6, 129.4, $129.1,122.4,121.8,113.9,113.8,113.7,113.6,100.3,85.8,72.0,71.9,71.4,55.6,55.4$, 55.2, 49.6, 48.1, 46.1, 46.0, 42.4, 39.1, 37.3, 36.5, 32.3, 32.2, 31.9, 31.8, 31.7, 27.5, 22.6, 22.3, 20.9, 20.7, 19.5, 13.7, 11.9. ESI MS: calcd for $\mathrm{C}_{71} \mathrm{H}_{92} \mathrm{O}_{18} 1232.6$, found $1255.2(\mathrm{M}+$ $\left.\mathrm{Na}^{+}\right), 1271.2\left(\mathrm{M}+\mathrm{K}^{+}\right)$. 
OSW-1 (1). ${ }^{1,6,9}$

To a mixture of $23(0.68 \mathrm{~g}, 0.5 \mathrm{mmol})$ in $\mathrm{CH}_{2} \mathrm{Cl}_{2}$ and $\mathrm{H}_{2} \mathrm{O}(10: 1,50 \mathrm{~mL})$ was added DDQ $(0.40 \mathrm{~g}, 1.8 \mathrm{mmol})$ at $\mathrm{rt}$. The reaction mixture was stirred at $\mathrm{rt}$ overnight and then concentrated in vacuum. The residue was purified by column chromatography to give $\mathbf{1}$ $(0.32 \mathrm{~g}, 79 \%)$ as a white solid. $[\alpha]_{\mathrm{D}}^{25}-40\left(c 0.3, \mathrm{CH}_{3} \mathrm{OH}\right) ;$ lit. ${ }^{1}-43\left(c 0.25, \mathrm{CH}_{3} \mathrm{OH}\right) .{ }^{1} \mathrm{H}$ NMR $\left(\mathrm{C}_{5} \mathrm{D}_{5} \mathrm{~N}, 500 \mathrm{MHz}\right): \delta 8.31(\mathrm{~d}, 2 \mathrm{H}, J=8.8 \mathrm{~Hz}), 7.07(\mathrm{~d}, 2 \mathrm{H}, J=8.8 \mathrm{~Hz}), 5.67(\mathrm{dd}, 1$ $\mathrm{H}, J=9.1,7.8 \mathrm{~Hz}), 5.55(\mathrm{~d}, 1 \mathrm{H}, J=7.9,6.3 \mathrm{~Hz}), 5.37(\mathrm{~d}, 1 \mathrm{H}, J=3.9 \mathrm{~Hz}), 5.11(\mathrm{~d}, 1 \mathrm{H}, J=$ $7.6 \mathrm{~Hz}), 4.79$ (s, $1 \mathrm{H}), 4.57(\mathrm{~d}, 1 \mathrm{H}, J=6.0 \mathrm{~Hz}), 4.39$ (brs, $1 \mathrm{H}$ ), 4.31 (dd, $1 \mathrm{H}, J=5.2,11.1$ Hz), 4.26-4.20 (m, 2 H), 4.20-4.12 (m, $3 \mathrm{H}), 3.81$ (brs, $1 \mathrm{H}), 3.73$ (s, $3 \mathrm{H}), 3.18$ (q, $J=7.4$ $\mathrm{Hz}, 1 \mathrm{H}), 1.96$ (s, $3 \mathrm{H}), 1.27$ (d, $3 \mathrm{H}, J=7.5 \mathrm{~Hz}), 1.06$ (s, $3 \mathrm{H}), 0.98$ (s, $3 \mathrm{H}), 0.87$ (d, $3 \mathrm{H}, J$ $=6.4 \mathrm{~Hz}), 0.84(\mathrm{~d}, 3 \mathrm{H}, J=6.4 \mathrm{~Hz}) .{ }^{1} \mathrm{H}$ NMR $\left(\mathrm{CD}_{3} \mathrm{OD}, 500 \mathrm{MHz}\right): 8.04(\mathrm{~d}, J=6.8 \mathrm{~Hz}, 2$ H), $7.02(\mathrm{~d}, J=6.8 \mathrm{~Hz}, 2 \mathrm{H}), 5.33(\mathrm{~d}, J=4.0 \mathrm{~Hz}, 1 \mathrm{H}), 4.93(\mathrm{t}, J=6.0 \mathrm{~Hz}, 1 \mathrm{H}), 4.86(\mathrm{~m}, 1$ H), $4.66(\mathrm{~d}, J=5.6 \mathrm{~Hz}, 1 \mathrm{H}), 4.14(\mathrm{~d}, J=4.8 \mathrm{~Hz}, 1 \mathrm{H}), 3.96(\mathrm{~m}, 2 \mathrm{H}), 3.87(\mathrm{~s}, 3 \mathrm{H}), 3.82$ (dd, $J=10.0,3.6 \mathrm{~Hz}, 1 \mathrm{H}), 3.76(\mathrm{~m}, 2 \mathrm{H}), 3.62(\mathrm{~m}, 4 \mathrm{H}), 3.47$ (dd, $J=9.6,1.6 \mathrm{~Hz}, 1 \mathrm{H})$, $2.92(\mathrm{q}, J=5.6 \mathrm{~Hz}, 1 \mathrm{H}), 2.47(\mathrm{~m}, 1 \mathrm{H}), 2.14-2.25(\mathrm{~m}, 4 \mathrm{H}), 1.70(\mathrm{~s}, 3 \mathrm{H}), 1.11(\mathrm{~d}, J=6.0$ $\mathrm{Hz}, 3 \mathrm{H}), 1.02$ (s, $3 \mathrm{H}), 0.82(\mathrm{~m}, 9 \mathrm{H})$; HR FAB MS: calcd for $\mathrm{C}_{47} \mathrm{H}_{68} \mathrm{NaO}_{15} 895.4456$, found $895.4459\left(\mathrm{M}+\mathrm{Na}^{+}\right)$.

\section{Supplementary Material}

Refer to Web version on PubMed Central for supplementary material.

\section{Acknowledgments}

This work was partially supported by a research grant from NIH/NCI (R01 CA95142).

\section{References}

1. Kubo S, Mimaki Y, Terao M, Sashida Y, Nikaido T, Ohmoto T. Phytochem. 1992; 31:3969.

2. Mimaki Y, Kuroda M, Kameyama A, Sashida Y, Hirano T, Oka K, Maekawa R, Wada T, Sugita K, Beutler JA. Bioorg. Med. Chem. Lett. 1997; 7:633.

3. Tamura K, Honda H, Mimaki Y, Sashida Y, Kogo H. Brit. J. Pharmacol. 1997; 121:1796. [PubMed: 9283720]

4. Morzycki JW, Wojtkielewicz A. Phytochem. Rev. 2006; 4:259.

5. Zhou Y, Garcia-Prieto C, Carney DA, Xu R, Pelicano H, Kang Y, Yu W, Lou C, Kondo S, Liu J, Harris DM, Estrov Z, Keating MJ, Jin Z, Huang P. J. Natl. Cancer Inst. 2005; 97:1781. [PubMed: 16333034]

6. Deng S, Yu B, Lou Y, Hui Y. J. Org. Chem. 1999; 64:202. [PubMed: 11674104]

7. Shi B, Tang P, Hu X, Liu JO, Yu B. J. Org. Chem. 2005; 70:10354. [PubMed: 16323845]

8. Yu W, Jin Z. J. Am. Chem. Soc. 2001; 123:3369. [PubMed: 11457074]

9. Yu W, Jin Z. J. Am. Chem. Soc. 2002; 124:6576. [PubMed: 12047177]

10. Guo C, Fuchs PL. Tetrahedron Lett. 1998; 39:1099.

11. Morzycki JW, Wojtkielewicz A. Carbohydr. Res. 2002; 337:1269. [PubMed: 12151206]

12. Xu Q, Peng X, Tian W. Tetrahedron Lett. 2003; 44:9375.

13. Suhr R, Thiem J. J. Carbohydr. Chem. 2004; 23:261.

14. Kruszewska A, Wilczewska AZ, Wojtkielewicz A, Morzycki JW. Pol. J. Chem. 2006; 80:611.

15. Qin H, Tian W, Lin C. Tetrahedron Lett. 2006; 47:3217.

16. Chen L, Xu Q, Huang H, Lin J, Tian W. Tetrahedron Lett. 2007; 48:3475.

17. Tschamber T, Adam S, Matsuya Y, Masuda S, Ohsawa N, Maruyama S, Kamoshita K, Nemoto H, Eustache J. Bioorg. Med. Chem. Lett. 2007; 17:5101. [PubMed: 17656091]

18. Williams JR, Gong H. Lipids. 2007; 42:77. [PubMed: 17393213] 
19. Wojtkielewicz A, Dlugosz M, Maj J, Morzycki JW, Nowakowski M, Renkiewicz J, Strnad M, Swaczynova J, Wilczewska AZ, Wojcik J. J. Med. Chem. 2007; 50:3667. and references therein. [PubMed: 17608396]

20. Matsuya Y, Masuda S, Ohsawa N, Adam S, Tschamber T, Eustache J, Kamoshita K, Sukenaga Y, Nemoto H. Eur. J. Org. Chem. 2005:803.

21. Shi B, Wu H, Yu B, Wu J. Angew. Chem. Int. Ed. 2004; 43:4324.

22. Morzycki JW, Wojtkielewicza A, Wołczynski S. Bioorg. Med. Chem. Lett. 2004; 14:3323. [PubMed: 15149699]

23. Matsuya Y, Itoh T, Nemoto H. Eur. J. Org. Chem. 2003:2221.

24. Ma X, Yu B, Hui Y, Miao Z, Ding J. Carbohydr. Res. 2001; 334:159. [PubMed: 11502272]

25. Ma X, Yu B, Hui Y, Miaob Z, Ding J. Bioorg. Med. Chem. Lett. 2001; 11:2153. [PubMed: 11514158]

26. Ma X, Yu B, Hui Y, Xiao D, Ding J. Carbohydr. Res. 2000; 329:495. [PubMed: 11128579]

27. Morzycki JW, Gryszkiewicz A, Jastrzebska I. Tetrahedron Lett. 2000; 41:3751.

28. Guo C, LaCour TG, Fuchs PL. Bioorg. Med. Chem. Lett. 1999; 9:419. [PubMed: 10091695]

29. Deng L, Wu H, Yu B, Jiang M, Wu J. Bioorg. Med. Chem. Lett. 2004; 14:2781. [PubMed: 15125932]

30. Peng W, Tang P, Hu X, Liu JO, Yu B. Bioorg. Med. Chem. Lett. 2007; 17:5506. [PubMed: 17826089]

31. Chaudhurrio NK, Nickolson R, Williams JG, Gut M. J. Org. Chem. 1969; 94:3767.

32. Magnus V, Vikic-Topic D, Iskric S, Kveder S. Carbohydr. Res. 1983; 114:209.

J Org Chem. Author manuscript; available in PMC 2011 September 27. 


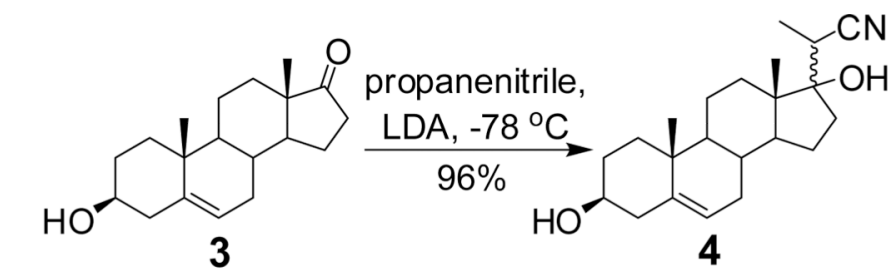

\begin{tabular}{r|}
$\left(\mathrm{CH}_{3}\right)_{2} \mathrm{CH}_{2} \mathrm{CH}_{2} \mathrm{MgBr}$, benzene, \\
reflex; then $\mathrm{NaOH}, \mathrm{MeOH}, \mathrm{rt}$,
\end{tabular}

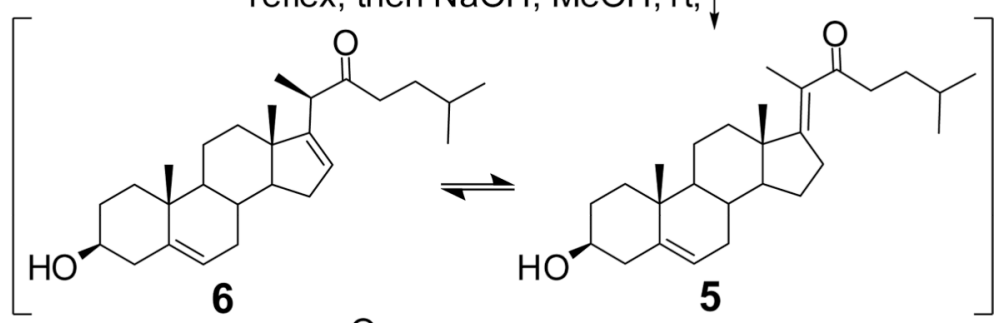

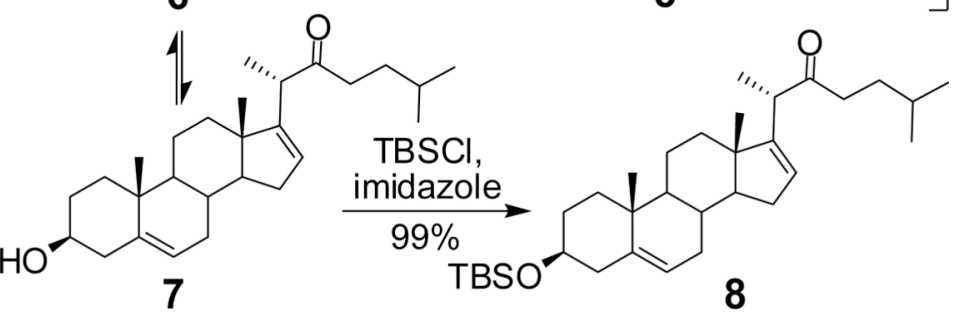

PTS $\mathrm{H}_{2} \mathrm{O}$, ethylene glycol, $96 \%$

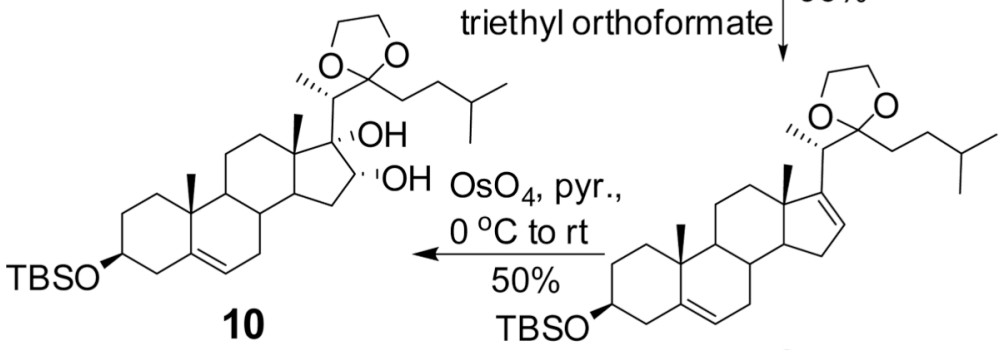

DMSO, oxalyl

chloride, $\mathrm{Et}_{3} \mathrm{~N}$,
$-78^{\circ} \mathrm{C}$ to it

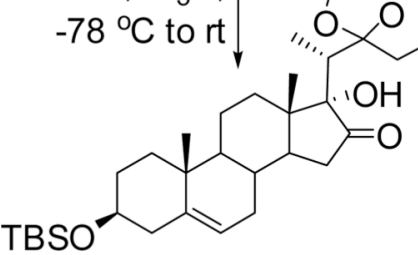

11
9

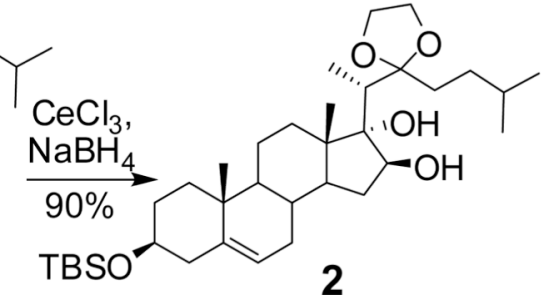

Scheme 1. 


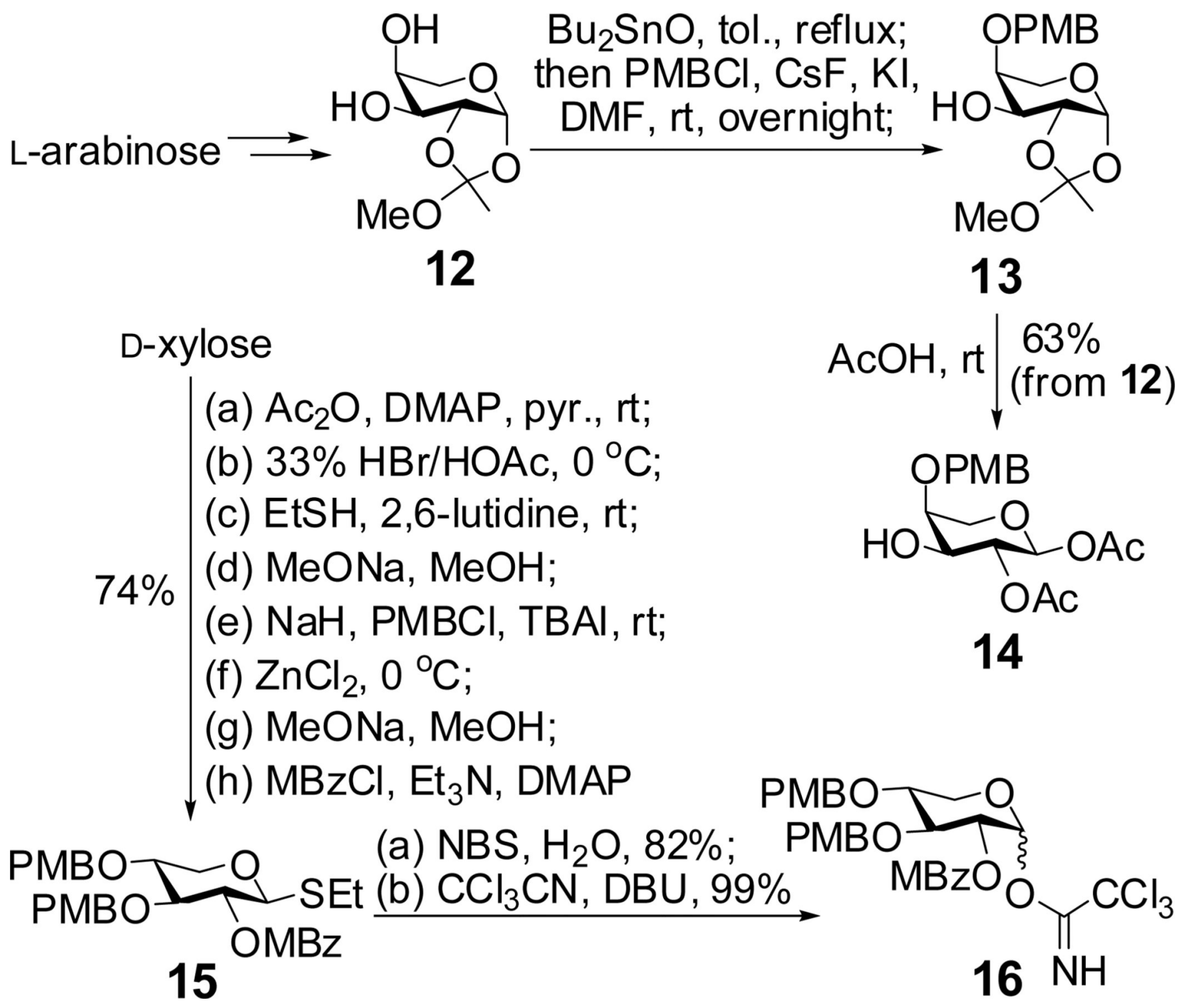

Scheme 2. 


$$
\begin{aligned}
& 14+15 \stackrel{\mathrm{NIS}, \mathrm{TfOH},-20^{\circ} \mathrm{C} \text { to rt; }}{\longrightarrow} 14+\stackrel{\mathrm{PMBO}}{\mathrm{PMBO}} \underset{\mathrm{MBZO}}{\mathrm{N}} \\
& 17 \text { (75\%) }
\end{aligned}
$$

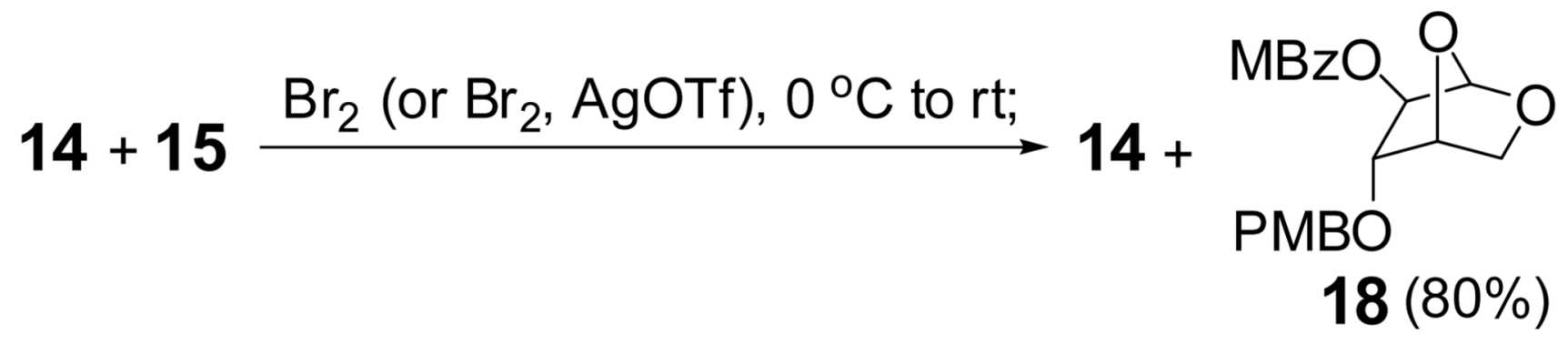

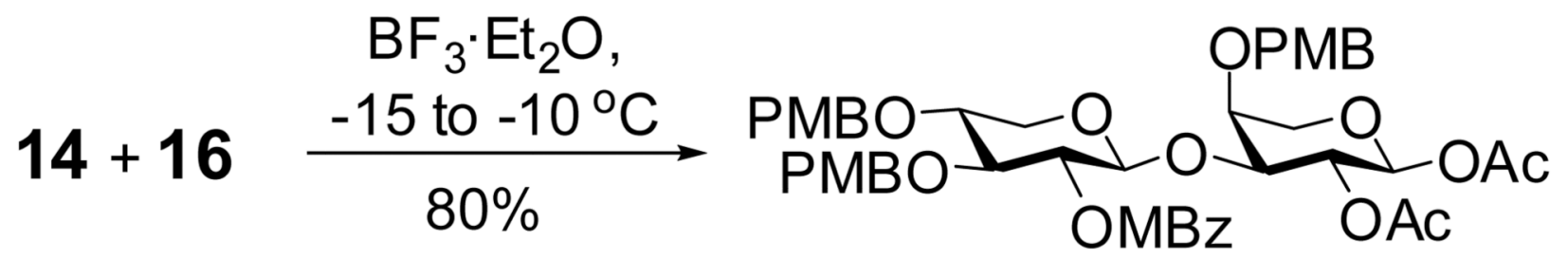

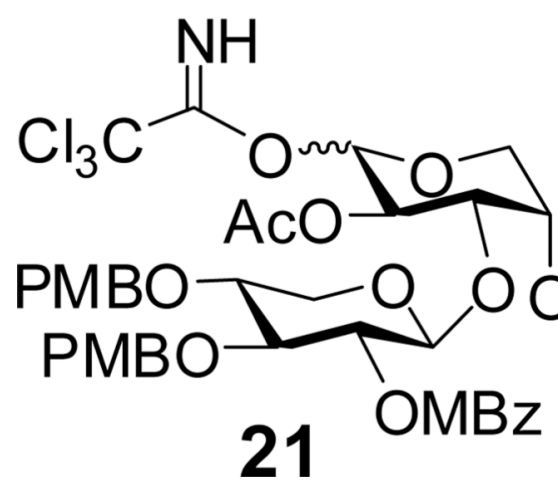

19

Scheme 3. 

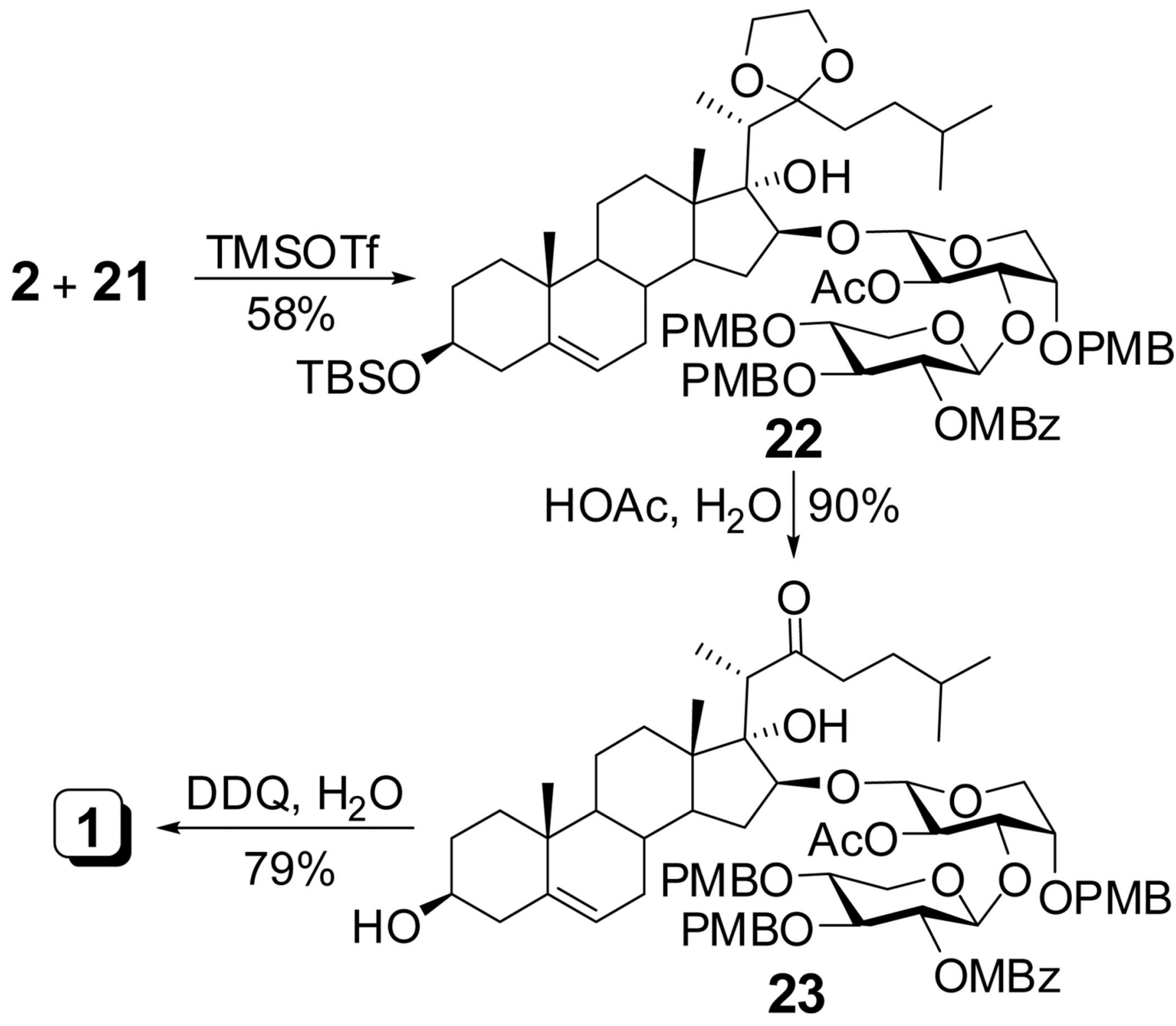

Scheme 4. 